\title{
PENGARUH BAURAN PEMASARAN TERHADAP KEPUASAN KONSUMEN RICHEESE FACTORY BINTARA KOTA BEKASI
}

\author{
Oleh: \\ Anik Ariyanti' ${ }^{1}$; Rochmad Fadjar Darmanto ${ }^{2)}$ \\ Sekolah Tinggi Ilmu Ekonomi IPWI Jakarta1,2) \\ ariyanti.anik@yahoo.co.id ${ }^{1}$; rochmadfadjar@yahoo.co.id ${ }^{2}$ )
}

\begin{abstract}
ABSTRAK
Tujuan penelitian ini adalah mengetahui pengaruh parsial dan simultan bauran pemasaran terhadap kepuasan konsumen Richeese Factory Bintara Kota Bekasi. Jenis penelitian yang digunakan adalah penelitian eksplanatori dengan pendekatan kuantitatif. Teknik pengumpulan sampel menggunakan Purposive Sampling dengan jumlah sampel sebnayak 100 orang responden. Metode pengumpulan data melalui penyebaran kuesioner. Teknik analiss data untuk penelitian ini adalah analisis deskriptif dan analisis regresi linier berganda. Berdasarkan hasil uji statistik yang dilakukan dapat diketahui bahwa secara simultan produk, harga, tempat dan promosi mempunyai pengaruh signifikan terhadap kepuasan konsumen. Secara parsial produk, harga, tempat dan promosi berpengaruh terhadap terhadap kepuasan konsumen Richeese Factory Bintara Kota Bekasi.
\end{abstract}

Kata kunci:

Bauran Pemasaran, Produk, Promosi, Harga, Tempat dan Kepuasan Konsumen

\section{PENDAHULUAN}

Bisnis kuliner di Indonesia saat ini mengalami pertumbuhan yang semakin pesat dan sangat signifikan pengaruhnya terhadap pertumbuhan perekonomian. Dari beberapa sumber menyebutkan bahwa pertumbuhan bisnis kuliner (industri makanan dan minuman) di Indonesia sudah mencapai angka $14 \%$ sd $20 \%$ di tahun 2014. Hal ini memberikan bukti bahwa bisnis kuliner lebih menjanjikan dan sangat diminati oleh masyarakat Indonesia.

Richeese Factory Bintara Kota Bekasi merupakan rumah makan yang menyediakan makanan dan minuman (food and beverage) cepat saji dengan menu yang variatif, harga yang terjangkau, tempat yang strategis, nyaman, aman, dan bersih, serta mempunyai promosi yang menarik dengan memasang plang bergambar orang dengan pose menunjukkan kenikmatan makanan yang disajikan. Richeese Factory Bintara Kota Bekasi merupakan salah satu restoran yang paling diminati di lingkungan Bintara Kota Bekasi. Dari hasil pengamatan peneliti memberikan bukti bahwa baik produk, harga, tempat dan promosi yang telah dilakukan, memberikan kepuasan kepada konsumennya. Kepuasan konsumen adalah perasaan senang atau kecewa seseorang yang berasal dari perbandingan antara kesannya terhadap kinerja (hasil) suatu produk dengan harapannya. Philip Kotler (2016:153). 
Indarjati (2001) mengatakan bahwa terdapat tiga macam kondisi kepuasan yang bisa dirasakan oleh konsumen berkaitan dengan perbandingan antara harapan dan kenyataan, yaitu jika harapan atau kebutuhan sama dengan layanan yang diberikan maka konsumen akan merasa puas. Jika layanan yang diberikan pada konsumen kurang atau tidak sesuai dengan kebutuhan atau harapan konsumen maka konsumen menjadi tidak puas. Kepuasan konsumen merupakan perbandingan antara harapan yang dimiliki oleh konsumen dengan kenyataan yang diterima oleh konsumen dengan kenyataan yang diterima oleh konsumen dengan kenyataan yang diterima oleh konsumen pada saat mengkonsumsi produk atau jasa.

Upaya dalam meningkatkan kepuasan konsumen, maka suatu perusahaan perlu mengukur pada bauran pemasarannya meliputi 4 (empat) P yaitu produk, harga, tempat dan promosi. Produk merupakan sesuatu yang ditawarkan kepada pasar untuk mendapat perhatian untuk dibeli dan digunakan untuk dapat memenuhi suatu keinginan dan kebutuhan. (Umar Husein, 2005). Harga menurut Tjiptono (2008) memiliki peranan utama dalam proses pengambilan keputusan para pembeli, yaitu peranan alokasi harga dan peranan informasi dari harga. Tempat merupakan gabungan antara saluran distribusi, lokasi dan keputusan pembelian yang berhubungan dengan penyampaian jasa kepada konsumen. Promosi menurut Kotler (2016) merupakan bagian dari kegiatan pemasaran, yang sangat diperlukan oleh perusahaan untuk meyakinkan konsumen terhadap produk yang ditawarkan.

\section{TUJUAN PENELITIAN}

Tujuan dari penelitian ini adalah untuk mengetahui pengaruh bauran pemasaran (produk, harga, tempat dan promosi) terhadap kepuasan konsumen Richeese Factory Bintara Kota Bekasi.

\section{TELAAH LITERATUR DAN PENGEMBANGAN HIPOTESIS Pemasaran}

Pemasaran adalah kegiatan untuk menawarkan produk/jasa kepada konsumen melalui media tertentu. Menurut Alex Nitisemito (2000), pemasaran didifinisikan sebagai semua kegiatan yang bertujuan memperlancar arus barang atau jasa dari produsen ke konsumen serta paling efisien dengan maksud untuk menciptakan permintaan efektif. Menurut Kotler (2012) pemasaran adalah suatu fungsi organsiasi dan serangkaian proses untuk menciptkan, mengkomunikasikan, dan memberikan nilai kepada pelanggan dan untuk mengelola hubungan pelanggan dengan cara yang menguntungkan organisasi dan pemangku kepentingannya.

\section{Bauran Pemasaran (Marketing Mix)}

Sofjan Assuari (2013) menyebutkan bahwa bauran pemasaran merupakan kombinasi variabel atau kegiatan yang merupakan inti dari sistem pemasaran, variabel mana yang dapat dikendalikan oleh sistem pemasaran, variabel mana yang dapat dikendalikan oleh perusahaan untuk mempengaruhi reaksi para pembeli atau konsumen. Dalam Buchari Alma (2016: 205) disebutkan bahwa marketing mix adalah strategi mengkombinasikan kegiatan-kegiatan marketing, agar tercipta kombinasi maksimal sehingga memunculkan hasil paling memuaskan..Sumarni dan Soeprihanto (2010:274) menyebutkan bahwa marketing 
mix adalah kombinasi dari variabel atau kegiatan yang merupakan inti dari sistem pemasaran yaitu:

a. Product (Produk)

Produk adalah setiap apa saja yang bisa ditawarkan di pasar untuk mendapatkan perhatian, permintaan, pemakaian atau konsumsi yang dapat memenuhi keinginan atau kebutuhan. Produk tidak hanya berupa barang tetapi bisa juga berupa jasa atau gabungan dari keduanya.

b. Price (Harga)

Harga adalah jumlah uang yang harus dibayarkan oleh konsumen untuk mendapatkan suatu produk yang diinginkannya. Harga sendiri di ukur dari nilai yang dirasakan oleh konsumen dari hasil produk yang ditawarkan. Jika tidak maka konsumen akan membeli produk lain dengan harga yang sama dari penjualan lain yang dilakukan oleh saingannya.

c. Place (Tempat)

Tempat dalam marketing mix biasa disebut dengan saluran distribusi, saluran dimana produk tersebut sampai kepada konsumen. Saluran distribusi adalah saluran yang digunakan oleh produsen untuk menyalurkan produk tersebut dari produsen sampai ke konsumen atau industri pemakai.

d. Promotion (Promosi)

Promosi adalah suatu bentuk komunikasi pemasaran. Komunikasi pemasaran adalah aktivitas pemasaran yang berusaha menyebarkan informasi, mempengaruhi/membujuk, dan/atau mengingatkan pasar sasaran atas perusahaan dan produknya agar bersedian menerima, membeli, dan loyal pada produk yang ditawarkan perusahaan yang bersangkutan.
Program pemasaran yang efektif harus dapat memadukan semua elemen baruan pemasaran ke dalam suatu program pemasaran terintegrasi yang dirancang untuk mencapai tujuan pemasaran perusahan dengan menghantarkan nilai bagi konsumen.

\section{Kepuasan Konsumen}

Kepuasan konsumen adalah perasaan konsumen terhadap satu jenis pelayanan yang didapatkannya. Kepuasan sering disebut juga dengan keadaan emosional, reaksi pasca pembelian yang dapat berupa kemarahan, ketidakpuasan, kejengkelan, kegembiraan atau kesenangan. Kepuasan konsumen memberikan banyak manfaat bagi perusahaan, dan tingkat kepuasan konsumen yang lebih besar. Dalam jangka panjang, akan lebih menguntungkan mempertahankan konsumen yang baik daripada terus menerus menarik dan membina konsumen baru untuk menggantikan konsumen yang pergi. Konsumen yang sangat puas akan menyebarkan cerita positif dari mulut ke mulut dan malah akan menjadi iklan berjalan dan berbicara bagi suatu perusahaan, yang akan menurunkan biaya untuk menarik konsumen baru.

Zeithaml dan Bitner (2013) mengartikan kepuasan adalah konsep yang jauh lebih luas dari hanya sekedar penilaian kualitas pelayanan, tetapi juga dipengaruhi oleh faktor-faktor lain. Kepuasan konsumen dipengaruhi oleh persepsi pelanggan terhadap kualitas pelayanan (jasa), kualitas produk, harga dan faktor situasi dan pribadi dari pelanggan. Kualitas pelayanan (jasa) merupakan fokus penilaian yang merefleksikan persepsi pelanggan terhadap lima dimensi spesifik dari pelayanan (jasa). Kepuasan lebih inklusif, yaitu kepuasan di tentukan oleh persepsi terhadap kualitas pelayanan (jasa), kualitas 
produk, harga, faktor situasi dan faktor pribadi. Ada beberapa aspek yang dapat mempengaruhi kepuasan pelanggan, yaitu 1) warranty costs (jaminan terhadap produk yang dijual), 2) penanganan terhadap komplain dari pelanggan, 3) market share, 4) costs of poor quality, dan 5) industry reports. Selain itu setiap perusahaan perlu melakukan pengukuran terhadap kepuasan pelanggan, untuk melihat umpan balik (feedback) maupun masukan untuk mengembangkan strategi peningkatan kepuasan konsumen.

Menurut Kotler (2008) metode yang tepat untuk mengukur kepuasan konsumen adalah: 1) sistem keluhan dan saran, 2) survei kepuasan pelanggan, 3) ghost shopping (pembeli bayangan), 4) lost customer analysis (analisa pelanggan yang beralih). Setiap perusahaan yang customer centered harus memberikan kesempatan bagi pelangganya untuk menyampaikan kritik, saran dan keluhan yang dirasakan, dengan memberikan formulir isian. Perusahaan yang responsif selalu mengukur kepuasan pelanggan dengan mengadakan survei berkala, dengan mengirimkan daftar pertanyaan atau menelpon suatu kelompok acak dari pembeli untuk mengetahui perasaan mereka terhadap berbagai aspek kinerja. Ghost shopping (pembeli bayangan) dilakukan dengan mempekerjakan beberapa orang untuk memerankan pelanggan atau pembeli potensial produk pesaing untuk melaporkan kekuatan maupun kelemahan yang mereka selama membeli produk perusahaan maupun produk pesaing. Analisis terhadap pelanggan yang beralih dapat dilakukan dengan cara menghubungi para pelanggan yang telah berhenti membeli sehingga dapat memahami mengapa hal itu terjadi dan bisa untuk mengevaluasi sebagai perbaikan.

\section{Gambar 1}

Kerangka Pemikiran

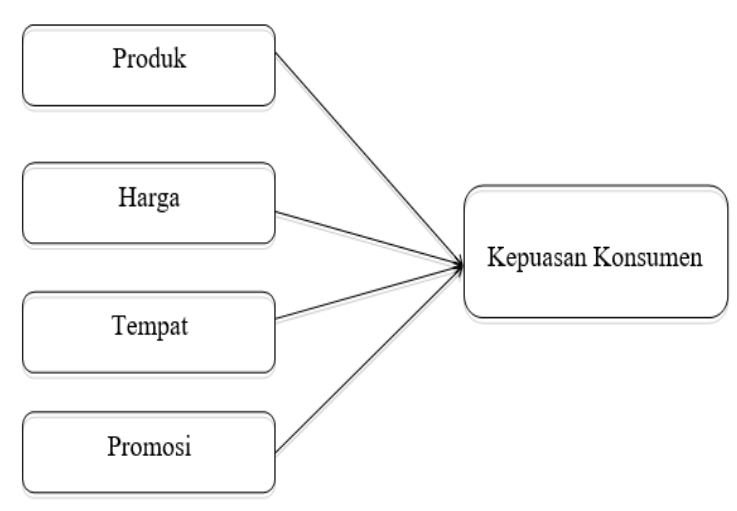

\section{METODE PENELITIAN}

Tempat dan Waktu Penelitian

Penelitian ini dilaksanakan di rumah makan siap saji Richeese Factory yang beralamat di Jalan Raya Bintara Kota Bekasi. Waktu yang digunakan untuk penelitian yaitu pada bulan AgustusNovember 2018.

\section{Populasi dan Sampel}

Populasi adalah wilayah generalisasi yang terdiri atas obyek atau subyek yang mempunyai kualitas dan karakteristik tertentu yang ditetapkan oleh peneliti untuk dipelajari dan kemudian ditarik kesimpulannya. (Sugiyono, 2012:115). Populasi dalam penelitian ini adalah para konsumen pada Richeese Factory Bintara Kota Bekasi.

Sampel dalam penelitian ini berjumlah 100 orang yang diambil dengan Teknik Purposive Sampling dari konsumen Richeese Factory yang berada di wilayah Bintara Kota Bekasi. Teknik purposive sampling dilakukan sebagai bentuk teknik yang secara sengaja mengambil sampel tertentu yang telah sesuai dan memenuhi segala persyaratan yang dibutuhkan. 


\section{Desain Penelitian}

Penelitian ini sifatnya explanatory research (penelitian penjelasan) dengan pendekatan kuantitatif. Tempat penelitian adalah di rumah makan Richeese Factory Bintara Kota Bekasi. Latar belakang pemilihan tempat penelitian tersebut karena peneliti melihat banyak sekali pengunjungnya dan rata-rata mereka membeli dengan antrian yang panjang.

\section{Definisi Operasional Variabel}

Definisi operasional dari masingmasing variabel penelitian adalah:

a. Bauran pemasaran atau "Marketing Mix" adalah kumpulan dari variabelvariabel pemasaran yang dapat dikendalikan yang digunakan oleh suatu badan usaha untuk mencapai tujuan pemasaran dalam pasar sasaran. Bauran pemasaran terdiri dari 4 komponen yaitu produk, harga, tempat/distribusi dan promosi.

b. Kepuasan konsumen adalah perasaan senang atau kecewa seseorang yang berasal dari perbandingan antara kesannya terhadap kinerja (atau hasil) suatu produk dan harapanharapannya (Zuliant Yamit, 2010).

\section{Metode Pengumpulan Data}

Pengumpulan data penelitian dengan observasi, komunikasi dan menyebarkan kuesioner ke konsumen yang berkunjung dan melakukan pembelian di Richeese Factory Bintara Kota Bekasi. Jawaban responden diukur dengan Skala Likert.

\section{Metode Analisis Data}

Untuk mengetahui tingkat kevalidan dan kehandalan data penelitian maka diukur dengan uji validitas dan reliabilitas data. Pengujian validitas dilakukan dengan program SPSS dengan pengambilan keputusan berdasarkan nilai Corrected Item-Total Correlation $>0,3$ maka pertanyaan dikatakan valid. Seluruh pertanyaan pada variabel indenpenden atau Bauran Pemasaran yang meliputi Produk (X1), Harga (X2), Tempat (X3) dan Promosi (X4) dikatakan valid karena nilai Corrected Item-Total Correlation $>0,3$, artinya seluruh instrumen layak digunakan sebagai alat ukur penelitian. Uji reliabilitas dengan menggunakan rumus Cronbach Alpha dan hasil yang diperoleh menunjukan nilai Cronbach Alpha untuk variabel independen atau Bauran Pemasaran (Produk, Harga, Tempat dan Promosi) diketahui $>0,60$, artinya ketiga variabel independen dinyatakan reliabel atau memenuhi persayaratan reliabel. Untuk mengukur data penelitian digunakan uji asumsi klasik, uji regresi berganda, uji koefisien determinasi dan uji hipotesis dengan uji $\mathrm{t}$ (uji parsial) dan uji $\mathrm{F}$ (uji simultan).

\section{HASIL PENELITIAN DAN PEMBAHASAN

Pada uji normalitas dengan menggunakan uji Kolmogorov Smirnov diketahui bahwa nilai Asymp. Sig (2-tailed) lebih besar dari 0,05, atau 0,063 (X1), 0,578 $(X 2)$ dan 0,160 (Y) >0,05. Berdasarkan hasil ini dapat dinyatakan bahwa data yang digunakan dalam penelitian ini berdistribusi normal. Pada uji multikolinieritas diketahui bahwa nilai Tolerance masing-masing variabel indenpenden adalah sebesar 0,666 > 10\% dan Variance Inflation Factor (VIF) untuk masing-masing variabel independen 1,732, $1,384,1,545$ dan $1,550<\mathrm{VIF}=10$, maka dapat disimpulkan bahwa antara variabel independen tidak terjadi multikolinieritas. Pada uji heteroskedastisitas dan dari grafik tergambar bahwa tidak ada pola yang jelas dan titik-titik menyebar di bawah serta di atas sumbu Y. Hal ini menunjukkan bahwa 
variabel independen tidak terjadi heteroskedastisitas.

\section{Koefisien Determinasi (R2)}

Hasil SPSS menunjukkan bahwa nilai koefisien determinasi atau Adjusted $\mathrm{R}$ Square $=0,415$ atau $41,5 \%$. Nilai ini berarti Produk (X1), Harga, (X2), Tempat (X3) dan Promosi (X4) memiliki pengaruh terhadap Kepuasan Konsumen ( $\mathrm{Y}$ ) sebesar 41,5\%, sisanya $58,5 \%$ diterangkan variabel lain.

\section{Regresi Linier Berganda}

Regresi linier berganda bertujuan untuk mengetahui pengaruh secara bersama-sama (simultan) antara dua atau lebih variabel independen dengan satu variabel dependen. Variabel independen pada penelitian ini meliputi Produk (X1), Harga (X2), Tempat (X3) dan Promosi (X4). Dan variabel dependennya adalah Kepuasan Konsumen (Y). Hasil SPSS menunjukkan persamaan regresi sebagai berikut:

Tabel 1

Uji Regresi

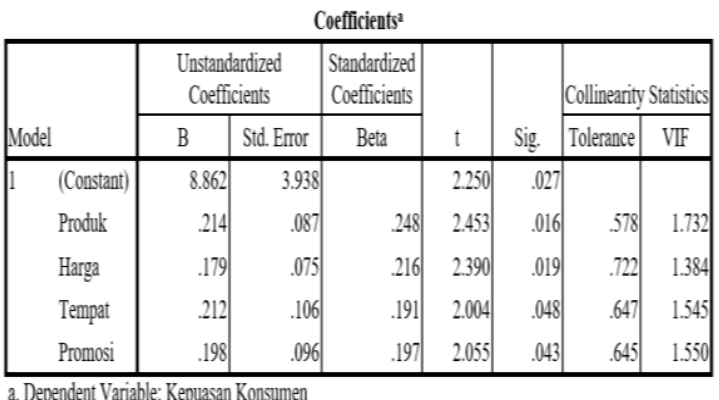

Sumber: SPSS, 2018

Pada tabel di atas menunjukkan bahwa Ý $=8,862+0,214 X 1+0,179 X 2+$ $0,212 X 3+0,198 X 4$. Persamaan ini mengartikan bahwa:

a. Nilai konstanta a $=8,862$, artinya jika tidak ada Produk (X1), Harga (X2), Tempat $(\mathrm{X} 3)$ dan Promosi (X4) atau $=$ 0 , maka Kepuasan Konsumen (Y) sebesar 8,862 . b. Nilai koefisien regresi Produk (X1) sebesar 0,214 artinya bila Produk (X1) ada peningkatan, maka Kepuasan Konsumen Richeese Factory Bintara Kota Bekasi akan mengalami peningkatan.

c. Nilai koefisien regresi Harga (X2) sebesar 0,179 artinya bila Harga (X2) ada peningkatan, maka Kepuasan Konsumen Richeese Factory Bintara Kota Bekasi akan mengalami peningkatan.

d. Nilai koefisen regresi Tempat (X3) sebesar 0,212 artinya bila Tempat (X3) ada peningkatan, maka Kepuasan Konsumen Richeese Factory Bintara Kota Bekasi akan mengalami peningkatan.

e. Nilai koefisen regresi Promosi (X4) sebesar 0,198 artinya bila Promosi (X4) ada peningkatan, maka Kepuasan Konsumen Richeese Factory Bintara Kota Bekasi akan mengalami peningkatan.

\section{Uji F}

Berdasarkan tabel Anova dalam SPSS, diketahui bahwa nilai Fhitung sebesar 18,568 dengan nilai signifikansi sebesar 0,000 . Nilai $F$ tabel dengan alpha 0,05 sebesar 2,31, sehingga Fhitung > Ftabel $(18,568>2,31)$ dengan signifikansi sebesar $0,00<0,05$. Hal ini menunjukkan bahwa variabel independen yaitu Produk (X1), Harga (X2), Tempat (X3) dan Promosi (X4) secara simultan berpengaruh signifikan terhadap Kepuasan Konsumen (Y).

\section{Uji $t$}

Pada uji statistic $\mathrm{t}$ dapat diketahui bahwa:

a. Nilai thitung Produk $(\mathrm{X} 1)>$ ttabel yaitu $2,453>1,984$ dan nilai signifikansi sebesar $0,016<0,05$, sehingga pengaruh Produk (X1) terhadap Kepuasan Konsumen (Y) 
signifikan. Produk mempunyai pengaruh signifikan terhadap kepuasan konsumen Richeese Factory Bintara Kota Bekasi.

b. Nilai thitung Harga $(\mathrm{X} 2)>$ ttabel yaitu 2,390>1,984 dan nilai signifikansi sebesar $0,019<0,05$ sehingga pengaruh Harga (X2) terhadap Kepuasan Konsumen (Y) signifikan. Harga mempunyai pengaruh signifikan terhadap kepuasan konsumen Richeese Factory Bintara Kota Bekasi.

c. Nilai thitung Tempat $(X 3)>$ ttabel yaitu 2,004 > 1,984 dan nilai signifikansi sebesar $0,048<0,05$ sehingga pengaruh Tempat (X3) terhadap Kepuasan Konsumen (Y) signifikan. Tempat mempunyai pengaruh signifikan terhadap kepuasan konsumen Richeese Factory Bintara Kota Bekasi.

d. Nilai thitung Promosi $(X 4)>$ ttabel yaitu $2,055>1,984$ dan nilai signifikansi sebesar $0,043<0,05$ sehingga pengaruh Promosi (X4) terhadap Kepuasan Konsumen (Y) signifikan. Promosi mempunyai pengaruh signifikan terhadap kepuasan konsumen Richeese Factory Bintara Kota Bekasi.

\section{Pembahasan}

\section{Model Pengaruh Bauran Pemasaran terhadap Kepuasan Konsumen}

Hasil perhitungan dapat diketahui bahwa Bauran Pemasaran yang meliputi Produk (X1), Harga (X2), Tempat (X3) dan Promosi (X4) secara simultan (bersamasama) berpengaruh terhadap Kepuasan Konsumen (Y). Nilai pengaruh dapat dilihat dari nilai Adjusted R Square sebesar 0,415. Hal ini menunjukkan bahwa model penelitian Bauran Pemasaran (Produk, Harga, Tempat dan Promosi) (bersama- sama) mampu menjelaskan $41,5 \%$ variasi Kepuasan Konsumen.

\section{Pengaruh Bauran Pemasaran terhadap Kepuasan Konsumen}

Produk (X1) mempunyai pengaruh terhadap Kepuasan Konsumen $(Y)$ dengan nilai koefisien regresi (b1) sebesar 0,214. Hal ini menunjukkan bahwa makin baik produk yang ditawarkan maka makin tinggi kepuasan konsumen Richeese Factory Bintara Kota Bekasi.

Harga (X2) mempunyai pengaruh terhadap Kepuasan Konsumen $(Y)$ dengan nilai koefisien regresi (b2) sebesar 0,179. Hal ini menunjukkan bahwa semakin tinggi kesesuaian harga yang ditawarkan maka makin tinggi kepuasan konsumen Richeese Factory Bintara Kota Bekasi.

Tempat (X3) mempunyai pengaruh terhadap Kepuasan Konsumen $(Y)$ dengan nilai koefisien regresi (b3) sebesar 0,212. Hal ini menunjukkan bahwa makin strategis tempat outlet maka makin tinggi kepuasan konsumen Richeese Factory Bintara Kota Bekasi.

Promosi (X4) mempunyai pengaruh terhadap Kepuasan Konsumen $(Y)$ dengan nilai koefisien regresi (b4) sebesar 0,198. Hal ini menunjukkan bahwa semakin intensif promosi yang dilakukan maka makin tinggi kepuasan konsumen Richeese Factory Bintara Kota Bekasi.

\section{KESIMPULAN}

a. Bauran pemasaran (produk, harga, tempat dan promosi) mampu menjelaskan 41,5\% variasi kepuasan konsumen Richeese Factory Bintara Kota Bekasi.

b. Bauran pemasaran (produk, harga, tempat dan promosi) masing-maing berpengaruh terhadap kepuasan konsumen Richeese Factory Bintara Kota Bekasi dengan arah positif. 


\section{SARAN}

a. Langkah yang paling strategi untuk dilakukan adalah dengan memperhatikan produk yang disajikan agar lebih inovatif lagi, bervariasi dan tentunya yang mampu menarik minat konsumen untuk menjadi pelanggan tetap yang setia.

b. Faktor harga, tempat dan promosi juga tetap menjadi prioritas yang harus diutamakan sehingga harga, tempat dan promosi terjangkau dan dapat dinikmati untuk semua kalangan masyarakat.

c. Richeese Factory Bintara Kota Bekasi harus tetap konsisten dengan harga, tempat dan promosi yang ditawarkan saat ini.

\section{DAFTAR PUSTAKA}

Alma, Buchari. (2016). Pengantar Bisnis. Bandung: Alfabeta

Assuari, Sofjan. (2013). Manajemen Pemasaran. Jakarta: Rajawali Pers Husein, Umar. (2005). Riset Pemasaran dan Perilaku Konsumen. Jakarta: PT Gramedia Pustaka Utama

Indarjati. (2001). Kepuasan Konsumen. Pranata No.1 Th.IV. Hal 70-75

Kotler, Philip dan Gary Armstrong. (2008). Prinsip-Prinsip Pemasaran. Edisi Keduabelas Jilid 2. Jakarta: Erlangga
Kotler, Philip dan Kevin L. Keller. (2008). Manajemen Pemasaran. Edisi Ketigabelas Jilid 1. Jakarta: Erlangga

Kotler. Philip dan Kevin L Keller. (2016). Marketing Management, 15th Edition. Pearson Education, Inc

Nitisemito, Alex. (2000). Manajemen Pemasaran. Jakarta: Ghalia Indonesia

Sugiyono. (2012). Metode Penelitian Kuantitatif, Kualitatif dan $R$ \& $D$. Bandung: Alfabeta

Sumarni, Murti dan John Soeprihanto. (2010). Pengantar Bisnis (Dasardasar Ekonomi Perusahaan). Edisi ke-5. Yogyakarta: Liberty Yogyakarta

Swasta, Basu. (2002). Manajemen Pemasaran. Edisi Kedua. Cetakan Kedelapan. Jakarta: Penerbit Liberty

Swasta, Basu dan Irawan. (2008). Manajemen Pemasaran Modern. Yogyakarta: Penerbit Liberty

Tjiptono, Fandy. (2008). Strategi Pemasaran. Edisi ke-3. Yogyakarta: Andi

Yamit, Zuliant. (2010). Manajemen Kualitas Produk dan Jasa. Yogyakarta: Ekonesia

Zeithaml, Valarie, Mary Jo Bitner, Dwayne D. Gramler. (2013). Service Marketing. McGraw-Hill International Edition 